\title{
再発した多形性腺腫（混合腫煌）の一例
}

小笠原 宫・吉村 史郎・王田 勝也・入谷現

\section{A Case of Recurrent Pleomorphic Adenoma \\ (Benign Mixed Tumor) in the Parapharyngeal Space}

\author{
Hiroshi Ogasawara, Shiro Yoshimura, Katsuya Toda \\ and Hiroshi Iritani
}

(Hyogo College of Medicine)

\begin{abstract}
The patient was a 20-year-old male who complained of swelling in submandibular area for a year. A large mass extended from the base of the skull to the upper border of the thyroid cartilage. The histopathological diagnosis was pleomorphic adenoma with peroral biopsy. Enucleation of the tumor was done through the a combination of peroral and cervical approaches. Histopathologically, components of the tumor consist of myoepithelia, stroma and a nest of squamous cell with keratinization, mitosis were infrequently encountered, and a part of the tumor capsule was very thin. The tumor seemed to arise from the mucosa of the palate. Salvage operation was done 5 years later, with a transparotid-cervical approach with mandibulotomy in the ramus mandible, which gave a wide field for surgery.
\end{abstract}

Key words : pleomorphic adenoma, parapharyngeal space, transparotid-cervical approach

はじめに

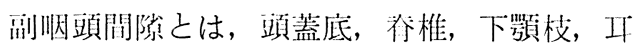
下腺，咽頭壁に囲まれた円錐帅の間䏚である。

この部位に発生する腫煌の多くは良性の多形性 腺腫や神経原性腫湯で，稀に㤠性リンパ腫等の 墨性腫瘍をみる112).

多形性腺腫は耳下腺または口蓋や眭頭側壁の 小唾液腺から生じ，自営症状に之しいためにし ばしば巨大になってから受彰する，組織学的に

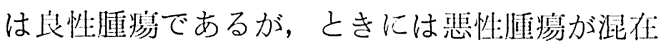
するととあある．生検により播種したり，解剖 学的に摘出困難な部位にあるため全摘できずに
再発すること屯多く，治㡜は必ずしも容易では ない.

我々は曰大な多形性腺種を生検の後に回内法 と外切開法とにより一塊として摘出したが， 5 年後に再発し頸部から経耳下腺法と下䫓枝の一 垗離断術によって再摘出を行った一例を経験し たので, 病理組織像と手術手技を中心に報告す る.

症例

症 例: 20才, 罗子, 学生

初晾：1980年 2 月 19 日

暨往歴および家族歴：特記すべき事なし 
現病歴：約 1 年前に右顎下部腫瘤に気付いた が放置していた。腫瘤は徐々に増大してきた が，自発痛，压痛，嚥下障害，呼吸困難はなか った. 学校検診で咽頭の腫脹を指摘され来院し た.

初診時所見：右軟口盍から咽頭側壁にか訬て 膨隆を認め, 顎下部と下顎後部に腫瘤を触知し た。咽頭と顎下部の腫瘤は双手診で可動性は良 く，一塊であった。右上咽頭腔は压排され，閉 寒していた．軟口蓋粘膜の可動性は一部不良で あった，耳鏡，鼻鏡所見には異常はなく，頸部 リンパ筑腫脹, 全身の異常所見も認めなかっ た。神経鞘腫または混合腫瘍を疑って腫湟に最 屯近い部位で生検が行われ，病理組織竞断は多 形性腺腫であった。

検査所見：唾液腺造影では顎下腺, 耳下腺へ の腫瘍の進展はなく，耳下腺は外側へ压排され ていた. CT-scan では右副咽頭間隙に巨大な 腫瘍索認め, 陰影は不均一で，一部に壊死を思 わせる部分も存在した。造影剂による陰影増強 は認めなかった。腫瘍の範囲は，上方は頭蓋 底，下力は甲状軟骨上縁，外側は下顎骨，前方 は翼状突起，後方は脊椎に接していた。耳下腺 と腫愓との間には間隙がみられた（図 1 ).

手術所見：1980年 4 月 2 日，経鼻插管による 全身麻酔下に，口内法と外切開法とを併用して 手術を施行した。腫瘍は弾性硬，平滑で被膜を むち，周囲組織とは容易に剥離できた。腫愓は 頼下腺, 耳下腺之は関係なく, 被膜を破ること

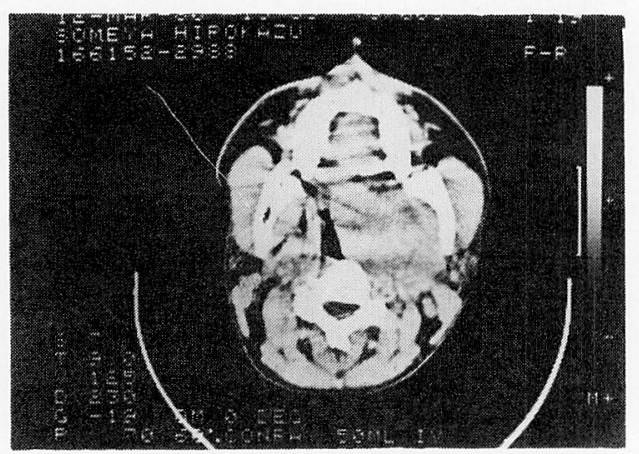

図Ｉ初回治療時の CT-scan
なく一塊として摘出できた，形は亜鈴型，重量 は $119 \mathrm{~g}$ で, 病理組織学的には多形性腺腫であ った(図 2 ).

病理組織所見：腫陽組織は，管状や充実性に 増生した筋上皮細胞之，角化学伴い扁平上皮へ 分化した細胞成分に富む上皮細胞之，軟骨様に 増生した非上皮細胞の基質とから構成されてい た．細胞の異型性はなく，核分裂像はほとんど 認めなかった。被膜は存在したが一部途中で途 ぎれたり，細胞成分の少ない軟骨様基質のとこ ろでは菲薄になったりしていた。

術後経過：手術後一侍的に開口障害が生じた が 3 ケ月後には消失し，構音障害や䀣下障害屯 なく経過した。しばらく米院がなく，1984年11 月にリンパ節腫脤と下䞄解部に腫瘤を触れ，再 発が確認された。

再発洔所見：腫場は初回とほぼ同じ位置に存 在し，上方は咽頭宿凹まで咽頭側壁の腫脹が認 められ，下方は舌背の高さまでであった，顎下 後部と下顎角に，小豆大と $25 \times 15 \mathrm{~mm}$ の弾性硬で 可動性良好な腫熘を触知した，耳下部の腫脹は 耳下腺と腫焬が一塊となっている屯のと思われ た. CT-sialogram では耳下腺深葉が腫煌を 取り囲むようにあり，耳下腺之腫瘍の間には間 隙は認められなかった。腫陽は造影剤による陰 影增強はみられず，陰影の不均一なところがみ

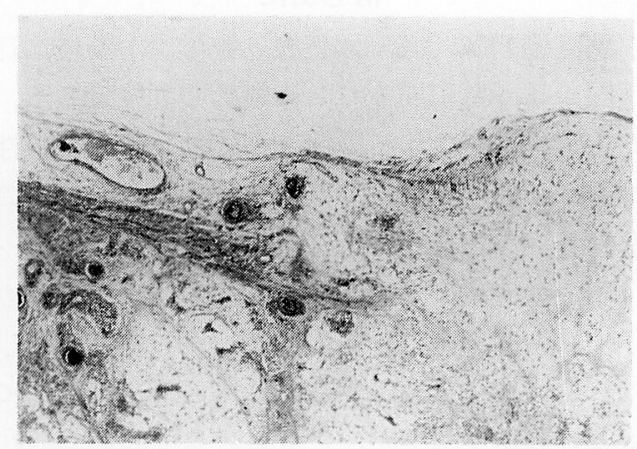

図 2 管状や充定性に增生した筋上皮終胞之, 角 化を伴った扁平上皮細胞，軟骨様の基質よ り腫演は構成されている. 被膜は一部途中 で途切れ，外側の薄い被膜のみになってい る. 
られた，頭蓋底，春椎，下䫓骨，翼状突起の破 壊はなく，乙れらに囲まれたところに腫陽が局 在した（図 3 ).

再手術所見：1985年 2 月 27 日，経口插管に上 る全身麻酔下に施行した。多形性腺腫の再発之 リンパ筋腫脹が存在したため, 準悪性腫湯とし て，上頸部リンパ節清掃と腫煌周囲の軟部組織 在含めて一塊とした摘出を試みた。 S 状皮覤切 開坴顎下部まで延長し，前回の手術疲痕部は広

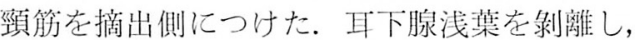

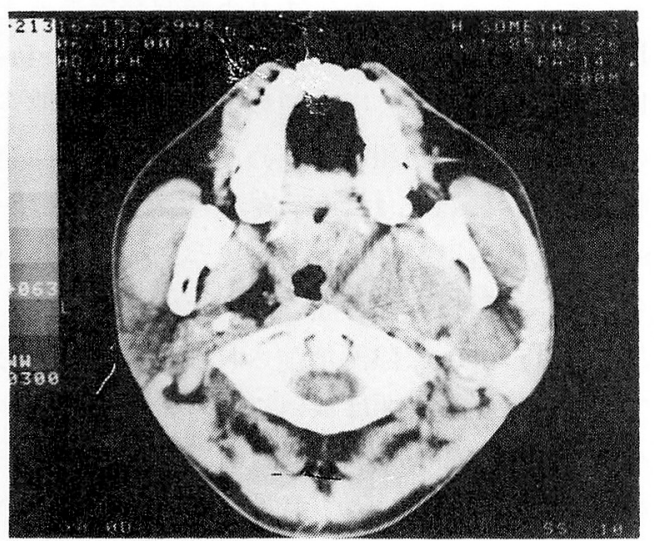

図 3 再発時の CT-sialogram

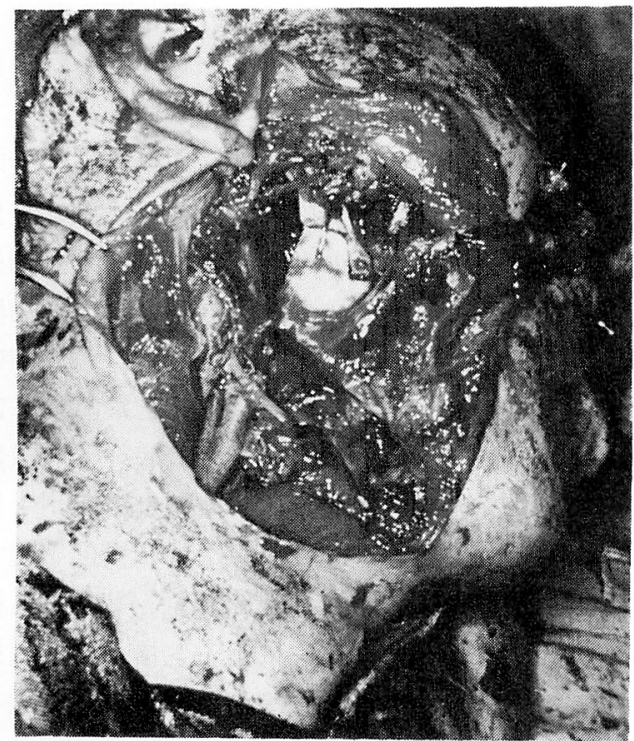

図 4 腫湯摘出後の術野
顔面神経は頸枝在除き上方へ举上した。下䫇骨 は図 4 のように下顎枝の下顎孔の上方で鈎状に 一時的に離断し，上前方に翻転した。 内頸静脈 は温存し，外頸動脈は舌動脈の上で結紮切断し た。腫瘍は耳下腺深渫と癒着しており，軟口蓋 瘢痕組織と屯癒着があった。これらと顎下腺， 下顎骨膜，顎二腹筋，荃突舌筋，内側翼突筋，咬 筋，口蓋骨水平板含含好腫瘍を摘出した．腫 瘍の上端は頸動脈孔におよんでいた。舌神経, 下歯槽神経，舌下神経，迷走神経，交感神経は 明視下に温存できた。下顎骨は鋼線で固定し， 軟口壒は煩粘膜弁で閉鎖した。

病理組織所見：初回時之同様に，管跀形成， 扁平上皮化成，軟骨様の非上皮細胞が混在する 多形性腺腫であった。核分裂像はほとんど認め なかった。リンパ節への転移はなく，頸部搬痕 部に孤立性の小さな腫陽鲑を認めた。

術後経過：手術後顔面神経麻痺と開口障害老 生じたが, 術後11ケ月の現在, 軽度の下口唇の 顔面神経麻痺以外の機能障害はなく，美容形態 にも問題はなく，悓時点では再発はみられな w.

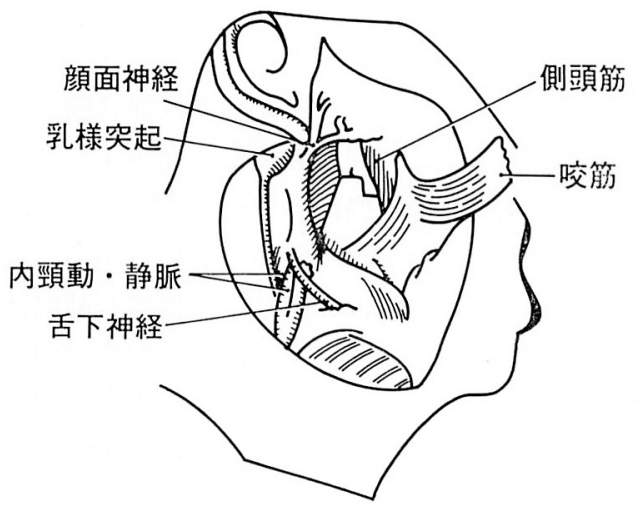




\section{考察}

副咽頭間隙の腫演で良性と考えられた場合に は生検の邀応はなく，むし賗に口腔から生検が 行われていたならば咽頭粘膜と咽頙収縮筋を含 めて腫煌を摘出すべきである．しかしてのよう に生検部位を含めて摘除しても，内頸動脈に浴 って播種されている可能性があり, 腫煬摘出は 不完全になることがある ${ }^{31}$. Mcllrath ${ }^{1)}$ む術中 の迅速組織搒断の用意は意味があるが，生検な しに摘出すべきであると述べている，本例は生 検が行われ，第 1 回手術封に被膜を破るととな く全摘出されたので, 生桧も再発の原困として 否定はできない。

多形性腺腫では病理組織学的に絒胞成分が少 なく, 軟骨粘液器質をむつ腄㴼は被膜が不完全 なことが多く再発しやすいといゔ)。 また多数 の細胞分裂像が観察される腫愓では, 再発, 転 移，悪性化しやすいといわれている51. 本例の 初回摘出柡本では図 1 亿示したように, 細胞成 分の少ない部分に一致して被膜が途ぎれるよう に薄くなった部位が認められ，腫陽は一塊とし て摘出されたが，散布されやすい状態であった と考えられた。細胞分裂像はほとんどなく，侮 休経過も昰性を思わせる所見はないが，将来覀 性化する可能性は否定できない. しかし瑟性混 合腫煬への変化は少なく，47例の悪性混合腫煌 のうち以前に良性腫陽として手術を受けた既往 のあるあのはそのうちの 9 例のみであったとい う報告むある6 .

墨性化には正常の喠液腺から瑟性混合腫愓が 発生するように良性混合腫恒加発生するとい う説と, 良性混合腫陽は発生侍に既に形態的, 細胞学的瑟性部分を含んでいるという説の二説 がある。しかし Livolsi' ${ }^{6}$ は, 悪性混合腫愓は

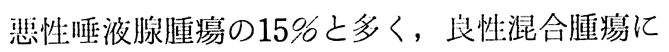
は多くは未分型腺癌が伴うことから上記二説に は否定的で, 墨性混合腫瘍は良性混合腫演之関 係なく発生すると述べている。

副咽頭間隙腫县の鑑別彰断には，自覚症状は 軽度なととが多いため役にたつことは少なく視
診や特に触診が重要である.

多形性腺腫の多くは耳下腺から発生する.耳 下腺腫陽の場合, 咽䫓側壁が腫脤するととは少 なく，腫脤をみた場合は耳下腺深葉原発か咽頭 粈膜原発かの鑑別が必要である。耳下腺原発で は腫場は咽頭収縮筋の外侧にあるため，咽頭粘 膜は腫愓に対し常に可動性をむっている。一 方, 粘膜原発では腫演は咽頭収縮筋の内側にあ るため，粘膜や筋肉の可動性は前者より不良で 疮着していることが多い，粘膜原発腫湯が成長 して筋肉を压排分制して副咽頭間隙へ進展す ることもあるが，多くは耳下腺原発であると Fluur ${ }^{7)}$ は述べている. Som 等8) は, CT-sialog ram で咽頭粘膜原発腫煌は耳下腺と腫煌と の間に線維と脂肪組織を認めるが，耳下腺原発 腫愓の場合にはこれが存在しないこと, CTscan で，造影剂によって陰影が增強されない むのは，血管撮影でむ血管の増生はみられず, 故に CT-scan で陰影增強されない腫瘍に対し ては血管撮影の必要はないとと，また悪性リン パ腫やリンパ節転移も造影剂で增強されない が，結邻状を呈する点が多少異ると述べてい る. 本例の初回治療時には, 耳下腺造影では耳 下腺が外方に压排され，CT-scan では腫煌と 耳下腺との閒に間隙を認め, 口蓋粘膜之腫焬之 の可動性は不良であったととから，口蓋粘膜原 発腫湯之考えられた。

副咽頭間㭞には, 内頸動脈, 内頸静脈, 舌咽 神経, 迷走神経, 副神経, 舌下神経, 頸部交感 神経が含まれるため手術手技は難しい，副咽頭 間隙腫瘍の摘出には従来から, 口内法や外切開 法が首独または両者を組み合わせて行われてい る. 口内法では小さな腫煬が適応となるが，口 内法では術野はせまく，また頭蓋底，下顎縁に 近いところや咽頭後壁の処置は困難で, 用手剶 離を行うことが多くなり血管や神経損傷を起す 危険がある. Shoss 等 ${ }^{10}$ は耳下腺深葉から発 生した混合腫湯は口内法による生検や摘出は播 種や手術恃の副損傷の危険があり，外切開法を 用いるべきと述べている，また，Som 等 ${ }^{8)}$ は茎 
状空起におよんでいる腫陽は，门内法のみでは 危険なので外切開法と組み合わせるべきである と述べている．外切開法は舌骨の高さで皮膚切 開をして副咽頭間隙に入るが，顎二腹筋，茎突 舌筋, 茎突舌骨䩚暴があり, 内側, 上方, 後方 の術野がとりにくい，下顎骨を上方に強く引い たり，下顎骨離断を行うと術野は搪がる．外切 開法のひとつとして経耳下腺法があり，主とし て耳下腺深葉から発生した腫演に用いられる。 耳下腺浅葉を除去した後, 顔面神経在露出し, これを温存して腫晹の摘出を行うというもので

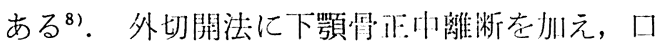
腔から咽頭に到達するJ法は，より巨大な耳下 腺原発以外の副咽頭間隙腫癔の摘出に適してい $3^{819)}$ このう法では頭蓋底の露出が可能で，IIIL 管の処䈯屯容易である，更に広く術野をとれば 耳下腺深葉を含めた摘出ができる.

本例の初回手術では，下方は甲状軟骨上縁ま であったため口内法と外切開法と在作用して, 下顎骨離断を行うことなく，肉服的には被膜に 覆われた腫場を一塊として摘出できた。しかし 組織学的には被膜の形成が菲溥であったり途ぎ れたりしており，盲目的䟝離が播種の原因之な ったことは否定できない。このような被膜が不 完全な巨大な腫湯や耳下腺深葉から発生した多 形性腺腫は経耳下腺法や下䫈骨一特離䉼術在行 い，術野を应大すると上もに出来るだけ健常組 織を含めた摘出が必要であると考える.

再手術洔には耳下腺深葉へ腫㰾が突出し, 翟 状突起，頭蓋底に摁していたので経耳下腺法を 用いた。耳下腺浅桬を分離し，顔面神経を遊襍 し，咬䇟を一部離断するととによって下㖽骨の 操作は容易となった。 下雨槽神経在保存し，か つ術後の下顎偏位を防ぐため，下顎孔の上方で 鈎状に下顎を一侍離断した。離断した下顎骨䦌 節突起侧を外前方に翻転させ，他方下顎体部侧 は前方に引くことにより広い術野を得ることが できた。つまり耳下腺の摘除と下顎枝の離断が 相持ち合って，後方や上方の視野は十分で，血 管，神経，頭蓋底の処置が可能であった。一部
口蓋战膜を合めた腫瘍摘出のため，内側の剝離 は几内法を用いたが，術野は十分でなかった。 組織学的には良性腫瘍であるために，下顎骨の 正中離断術式の適応はためらわれるが，経耳下 腺法と併用した搪大手術は一考值する. 本例 に行った術式でも十分に頭蓋底を視野に入れる ことができ，III管や神経の保存が可能であった ことを強調したい，本例では，顔面神経，舌神 経，舌下神経，舌栶神経，下歯槽祅経，副神 経, 頸部交感神経は保存され, 開口障害, 構音 不全もきたさなかったが，再々発や悪性腫瘍の 出現には今後長期の経過観察が必耍である.

\section{まとめ}

副咽䫓間隙に発生した巨大な腫瘍のため, 顎 下部腫湯を主诉として受診した，20才男子の多 形性腺腫の一例安報告した。

生検後, 口内法と外切開法を用い一塊として 摘出したが 5 年後に再発した。

病理組織学的には，管腔形成，痌平上皮，非 上皮細胞よりなる多形性腺腫で，被膜の一部は 莎く途ぎれたようになっていた。この薄い被膜 が原困で生㭘洔または摘出洔に腫癔細胞が散布 され再発したと考えられた。

腫瘍は口素粘膜から発生し测咽頭間隙へ進展 したと考えた。

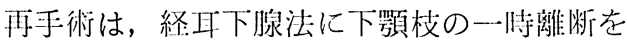
加えることにより站蓝底む㺫视下になり腫演摘 出が间能となった。

\section{参考文献}

1) McIlrath DC, et al : Tumors of the parapharyngeal region. Surg Gyn Obst $114: 88 \sim$ 94, 1963.

2) Work WP and Hybels RL : A study of tumors of the parapharyngeal space. Laryngoscope $84: 1748 \sim 1755,1974$.

3 ) Work WP: Tumors of the parapharyngeal space. Tr Am Acad Ophth Otol 73:389 394, 1969.

4) Naeim F, et al : Mixed tumors of the salivary glands. Arch Pathol Lab Med 100: 
271 275, 1976.

5) Ryan RE, et al : Cellular mixed tumors of the salivary glands. Arch Otolaryngol 104 : 451 453, 1978.

6) Livolsi VA and Perzin KH : Malignant mixed tumors arising in salivary glands. I. Carcinomas arising in benign mixed tumors : a clinico-pathologic study. Cancer $39: 2209 \sim$ 2230, 1977.

7) Fluur E : Parapharyngeal tumors. Arch Otolaryngol $80: 557 \sim 565,1964$.

8) Som PM, Biller HF and Lawson $W$ : Tumors of the parapharyngeal space, preoperative evaluation, diagnosis and surgical approaches. Ann Otol Rhinol Laryngol 90 Suppl $80: 3 \sim 15,1981$.

9) 弓崎明輝, 茂木五郎, 藤吉達也：副咽頭問隙腫煬

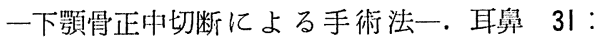
493 496, 1985.

10) Shoss SM, Donovan DT and Alford BR : Tumors of the parapharyngeal space. Arch Otolaryngol III:753 757, 1985.

別刷請求先：小笠原 寛 厂663 西宮市武庫川町 $1-1$

兵庫医科大学耳鼻咽诶科学教室 